\title{
Knowledge, attitude and practice of people with HIV regarding a healthy lifestyle: clinical trial
}

\author{
Conhecimento, atitude e prática de pessoas com HIV sobre estilo de vida saudável: ensaio clínico \\ Conocimiento, actitud y práctica de personas con VIH acerca del estilo de vida saludable: ensayo clínico
}

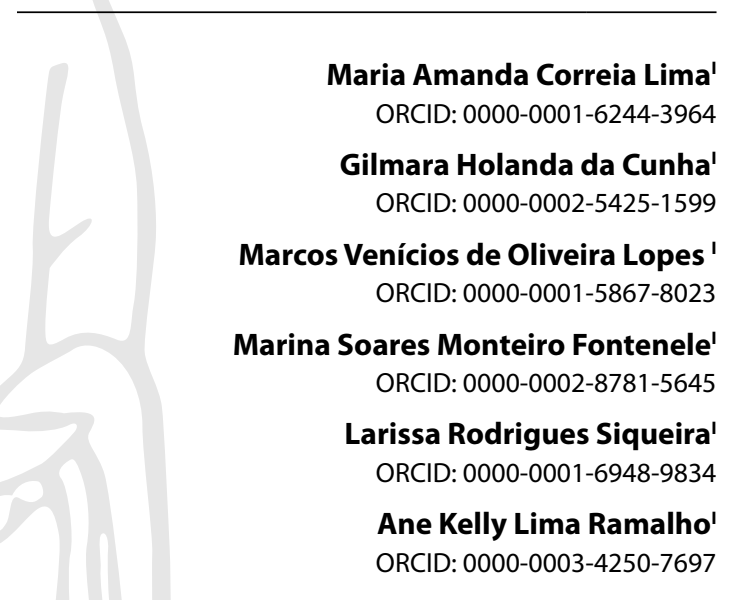

'Universidade Federal do Ceará. Fortaleza, Ceará, Brazil.

How to cite this article:

Lima MAC, Cunha GH, Lopes MVO, Fontenele MSM, Siqueira LR, Ramalho AK. Knowledge, attitude and practice of people with HIV about healthy lifestyle: clinical trial.

Rev Bras Enferm. 2022;75(5):e20210307. https://doi.org/10.1590/0034-7167-2021-0307

Corresponding author:

Gilmara Holanda da Cunha

E-mail: gilmaraholandaufc@yahoo.com.br

EDITOR IN CHIEF: Antonio José de Almeida Filho ASSOCIATE EDITOR: Hugo Fernandes

Submission: 06-07-2021

Approval: $10-08-2021$

\begin{abstract}
Objective: To evaluate the effectiveness of an educational booklet on the knowledge, attitude and practice of a healthy lifestyle in people with HIV. Methods: Randomized clinical trial with 75 intervention group patients using the booklet, and 75 control group patients undergoing usual service care. Data collection occurred in four moments, with a Survey pertaining Knowledge, Attitude and Practice. Nonparametric analysis of variance of repeated measures was used. Results: 70 participants in the intervention group and 74 in the control group completed the study. In terms of knowledge, there was no difference between groups, the booklet impact came late, increasing after reassessments. In attitudes, there was a difference between groups in the two- and four-month reassessments compared to the baseline. In practices, there was a difference in the intervention group compared to the control group at two, four, and six months compared to baseline. Conclusion: The booklet was effective in improving healthy lifestyle knowledge, attitudes, and practices in people with HIV. Descriptors: HIV; Life Style; Health Knowledge, Attitudes, Practice; Educational Technology; Health Promotion.
\end{abstract}

\section{RESUMO}

Objetivo: Avaliar a efetividade de uma cartilha sobre o conhecimento, atitude e prática do estilo de vida saudável em pessoas com HIV. Métodos: Ensaio clínico randomizado com 75 pacientes no grupo intervenção com cartilha, e 75 no controle, com cuidado habitual do serviço. Coleta de dados em quatro momentos, com Inquérito de Conhecimento, Atitude e Prática. Utilizou-se análise de variância não paramétrica de medidas repetidas. Resultados: Concluíram o estudo 70 participantes no grupo intervenção e 74 no controle. No conhecimento, não houve diferença entre grupos, o impacto da cartilha foi tardio, aumentando nas reavaliações. $\mathrm{Na}$ atitude, houve diferença entre grupos nas reavaliações de dois e quatro meses comparadas à basal. Na prática, houve diferença no grupo intervenção no controle aos dois, quatro e seis meses comparados à basal. Conclusão: A cartilha foi efetiva para melhorar o conhecimento, atitude e prática sobre estilo de vida saudável em pessoas com HIV.

Descritores: HIV; Estilo de Vida; Conhecimentos, Atitudes e Prática em Saúde; Tecnologia Educacional; Promoção da Saúde.

\section{RESUMEN}

Objetivo: Evaluar efectividad de una cartilla sobre el conocimiento, actitud y práctica del estilo de vida saludable en personas con VIH. Métodos: Ensayo clínico randomizado con 75 pacientes en grupo intervención con cartilla, y 75 en control, con cuidado habitual del servicio. Recolecta de datos en cuatro momentos, con Averiguación de Conocimiento, Actitud y Práctica. Utilizado análisis de variancia no paramétrica de medidas repetidas. Resultados: Concluyeron el estudio 70 participantes en grupo intervención y 74 en control. En conocimiento, no hubo diferencia entre grupos, el impacto de la cartilla fue tardío, aumentando en las reevaluaciones. En actitud, hubo diferencia entre grupos en las reevaluaciones de dos y cuatro meses, comparadas al basal. En la práctica, hubo diferencia en grupo-intervención en control a los dos, cuatro y seis meses comparados al basal. Conclusión: La cartilla fue efectiva para mejorar el conocimiento, actitud y práctica sobre estilo de vida saludable en personas con $\mathrm{VIH}$.

Descriptores: VIH; Estilo de Vida; Conocimientos, Actitudes y Práctica en Salud; Tecnología Educacional; Promoción de la Salud. 


\section{INTRODUCTION}

Antiretroviral therapy (ART) has increased the life expectancy of people with HIV, and the infection that was once fatal has become a chronic health condition ${ }^{(1)}$. However, people living with HIV (PLHIV) have become more susceptible to chronic noncommunicable diseases (CNCD), as studies show an increased frequency of comorbidities compared to the general population $^{(2-4)}$. Although the exact causes are not defined, the increased risk for CNCD in PLHIV appears to be multifactorial, due to the immunological activation of HIV, with ART and its long-term side effects, aging, and an unhealthy lifestyle aggravating the situation synergistically(5).

It is known that lifestyle plays an important role in the development of CNCD, and research shows that PLHIV generally have a less healthy lifestyle $e^{(3,6)}$, with habits that negatively affect their quality of life ${ }^{(7)}$. Lifestyle is a broad concept that analyzes the person in the physical, mental, spiritual, and social areas, in relation to choices and way of life ${ }^{(8)}$. A balanced diet, physical exercise, stress control, preventive behavior, and non-use of drugs are lifestyle components that can be adopted for good health ${ }^{(9)}$.

An unhealthy lifestyle is associated with approximately $40 \%$ of global mortality, and changes in this aspect are related to improved Knowledge, Attitudes, and Practices, in addition to providing a supportive environment for healthy behavior ${ }^{(10)}$.Thus, the Knowledge, Attitudes and Practices Survey (KAP) makes it possible to measure these aspects for the educational diagnosis of populations. This instrument can be adapted to different situations, evaluating interventions for the individual or the community and planning health promotion actions ${ }^{(11)}$. The patient's knowledge about the disease and self-care are essential to achieve goals in health monitoring. The management of CNCD requires autonomy and empowerment of patients for self-care ${ }^{(12)}$. It is assumed that increasing knowledge about a healthy lifestyle encourages the modification of inappropriate behaviors and intensifies preventive measures, while interventions that increase motivation are essential for changes in attitude and practice ${ }^{(13)}$.

In this context, educational technologies have been built, evaluated, and used by health professionals to provide continued care for patients ${ }^{(14-15)}$. Among the educational technologies, there are booklets, which favor a clear and objective approach to information and self-care practices. They reaffirm the guidelines of health professionals outside the office, as generally not all information is well understood during consultations ${ }^{(16-17)}$.

Despite the variety of educational materials available, this study is justified by the need to evaluate an educational technology for adults with HIV. It is based on providing health information to empower and strengthen autonomy and responsibility to achieve a healthier lifestyle. The educational booklet was the chosen strategy because it is a material that can be taken home and is easy to access and understand. The relevance of the research lies in the scientific contribution to the areas of health, nursing, and assistance to PLHIV, as it provides complementary material to outpatient consultations in order to insert care into the patient's daily life.

There is a gap in the literature regarding the topic, since, to date, no clinical trial studies that have used the KAP Survey in their assessment of healthy lifestyle in PLHIV have been identified. Thus, as an innovation, we sought to evaluate the effectiveness of a material aimed exclusively at adults with HIV, on relevant topics about body weight control, healthy eating, physical exercise, smoking, alcohol and other drugs, stress control, and drug therapy.

\section{OBJECTIVE}

To evaluate the effectiveness of an educational booklet on the knowledge, attitudes, and practices of a healthy lifestyle in people with HIV.

\section{METHODS}

\section{Ethical aspects}

Following Resolution 466/12(18), the project was approved by the Research Ethics Committees of the Federal University of Ceará and of the Walter Cantídio University Hospital. The study was registered in the Brazilian Registry of Clinical Trials, under No. RBR-7p6vsr.

\section{Study design, period, and location}

Randomized, controlled and parallel clinical trial, carried out at the Infectology Outpatient Clinic of the Walter Cantídio University Hospital, in Fortaleza, State of Ceará, Brazil. Data collection took place between January 2019 and July 2020. The references of the Consolidated Standards of Reporting Trials (CONSORT) were adopted ${ }^{(19)}$.

\section{Population, sample, inclusion and exclusion criteria}

The study population consisted of PLHIV undergoing outpatient follow-up. A sample was calculated to provide $90 \%$ power and $95 \%$ confidence to detect a significant difference between the intervention and control groups regarding the proportion of patients with an improvement of at least $20 \%$ in the KAP Survey score. It was established that a $25 \%$ difference should be detected between the groups for guide effectiveness, that is, the guide would increase at least $25 \%$ the proportion of patients with a minimum improvement of $20 \%$ in the KAP Survey score. A percentage of $15 \%$ was added for possible losses, and the sample was estimated at 75 patients per group.

Inclusion criteria were: PLHIV aged 18 years or over, of both sexes, on ART for at least six months, having a landline or cell phone, ability to read the booklet and understand it, obtain scores equal or above 35 on the Health Literacy Scale ${ }^{(20)}$. Exclusion criteria: pregnancy, disabling mental illness, living on the streets, living in shelters, or being deprived of liberty. Discontinuity criteria were: inability to follow-up, hospitalization, change of health care location, unreachable by telephone, and death.

\section{Study protocol}

The booklet titled" My Motivation for Change Booklet! Practices for the Promotion of a Healthy Lifestyle" was constructed and validated in a previous study ${ }^{(21)}$, with a theoretical framework 
based on the Transtheoretical Model of Behavior Change ${ }^{(22)}$. It is composed of 30 pages with text and color illustrations and covers six areas: body weight control; healthy eating; engaging in physical exercise; tobacco, alcohol and other drugs; stress control; and drug treatment. At the end, there are two pages for recording consultations, blood pressure (BP), weight, body mass index (BMI), viral load, CD4+ T lymphocyte count, and medications. There are also two pages for personal goals, with a healthy eating and exercise calendar.

The clinical trial had three stages: recruitment and randomization; intervention; and post intervention. PLHIV were recruited from the Walter Cantídio University Hospital while awaiting a routine consultation.

During recruitment and randomization, the research was explained to the participants, and the Free Informed Consent Form (FICF) and the Health Literacy Scale ${ }^{(20)}$ were handed for completion. This scale is self-applicable, has been translated and adapted to Brazilian Portuguese, and has 14 questions on a five-point Likert scale (1 to 5), with an assessment of health literacy in three levels: functional (five items), interactive (five items), and critical literacy (four items). The result occurs by the sum of points of the items: if equal to or greater than 35 points, the literacy is adequate ${ }^{(20,23)}$; and the participant, included. Randomization occurred according to the days of the week through random allocation ${ }^{(24)}$ by an exclusive researcher for this function. Previously, Mondays and Wednesdays were drawn for allocation of participants in the intervention group, and Tuesdays and Thursdays, for control. Randomization occurred in this way so that patients in both groups could not meet. The intervention group was instructed not to share the booklet with other patients; and, in the case of more than one PLHIV in the household, they were allocated to the same group.

In the intervention stage, there was a baseline assessment of the groups. Different researchers worked in the intervention or control groups so as not to interfere with the results, applying two instruments.

The first was the Sociodemographic, Epidemiological, Clinical and Risk Factor Form for CNCD in PLHIV ${ }^{(25-26)}$, with the variables: date of birth, sex, skin color, education, marital status, occupational status, family monthly income, exposure category, sexual orientation, lives with a partner, anti-HIV serology, time since diagnosis and ART, antiretrovirals, CD4+ T lymphocyte count, viral load, salt consumption, alcohol, smoking, illicit drugs, physical exercise, personal and family history of CNCD, consumption of fruit, vegetables, fried foods, fatty foods, diagnosis of CNCD, and drugs used. BP, weight, height, BMI, and waist circumference were measured.

The second instrument was the KAP Survey, built and validated in a previous research ${ }^{(27)}$, to be used after reading the booklet. It consists of 31 items, divided into three domains with answer options: 1) Knowledge domain (10 questions; 1 - Yes; 2 - No; 3 - I don't know); 2) Attitude domain (10 questions; 1 - Yes; 2 - No; 3 - I do not perform set specific orientation); 3) Practice domain (11 questions; 1 - Yes; 2 - No; 3 - I don't know/never). The score is considered appropriate if equal to or greater than $70 \%$ of correct answered items. After baseline evaluation, the control group received the usual care, which was a medical appointment. The intervention group received the booklet individually in a private office and read the material completely with the researcher at their side to clarify any doubts. Then, the patient took the booklet home, with guidance on reading it fortnightly. The procedures in this phase lasted an average of one hour for the intervention group and 30 minutes for the control group.

During post-intervention, patients were re-evaluated in the second, fourth, and sixth months through telephone calls for reapplication of the KAP Survey. Two exclusive telephones were used for the research, and the data collection team consisted of nine researchers. For blinding, four researchers were responsible for the intervention group, four for control, without knowing which group the patients belonged to. The ninth researcher recruited participants, randomized, and made lists for calls, as those responsible for the reassessments did not know which group the patients belonged to. The Standard Operating Procedures (SOPs) were followed for study presentation, randomization, application of the FICF, forms, booklet, and telephone calls.

\section{Statistics and analysis of results}

Absolute frequencies and percentages were calculated for nominal variables; and mean, median, standard deviation, and interquartile range for quantitative. Adherence and normal distribution were verified with the Shapiro-Wilk test. Differences in proportions between nominal variables at baseline were verified by Pearson's chi-squared test. When more than $25 \%$ of the frequencies in contingency tables were less than 5, the Fisher test or extension for RxS tables (Fisher-Freeman-Halton test) was applied. Among quantitative variables, baseline differences were analyzed using the Mann-Whitney test, for identifying non-normality of variables. For comparison between groups, parametric analysis of variance was performed for repeated measures, but tests of sphericity and normality for subgroups showed a violation of these assumptions. A non-parametric repeated measures analysis of variance was performed, based on the aligned rank transformation approach ${ }^{(28)}$, in which the ranks are transformed; and the alignment, obtained for each effect of interest (group, time, and interaction between group and time).

Repeated measures analysis of variance was applied using the aligned ranks to establish the sources of variation (group, time, and interaction) that would explain differences in the values of the response variables. This analysis was based on $\mathrm{F}$ tests for each source of variation. Comparisons by confidence intervals and application of contrasts for response measures obtained by group and time are presented, using t-tests for two-by-two comparisons of the aligned ranks. T-tests were applied to analyze differences between aligned ranks of the intervention and control groups for each assessment time. A significance level of $5 \%$ was adopted, considering $p<0.05$ as statistically significant. The statistical software R (version 3.2.2) was used for statistical procedures.

\section{RESULTS}

Of the 198 PLHIV recruited, 30 were excluded. Seventy participants in the intervention group and 74 in the control completed the study. The clinical trial flowchart is described in Figure 1. 


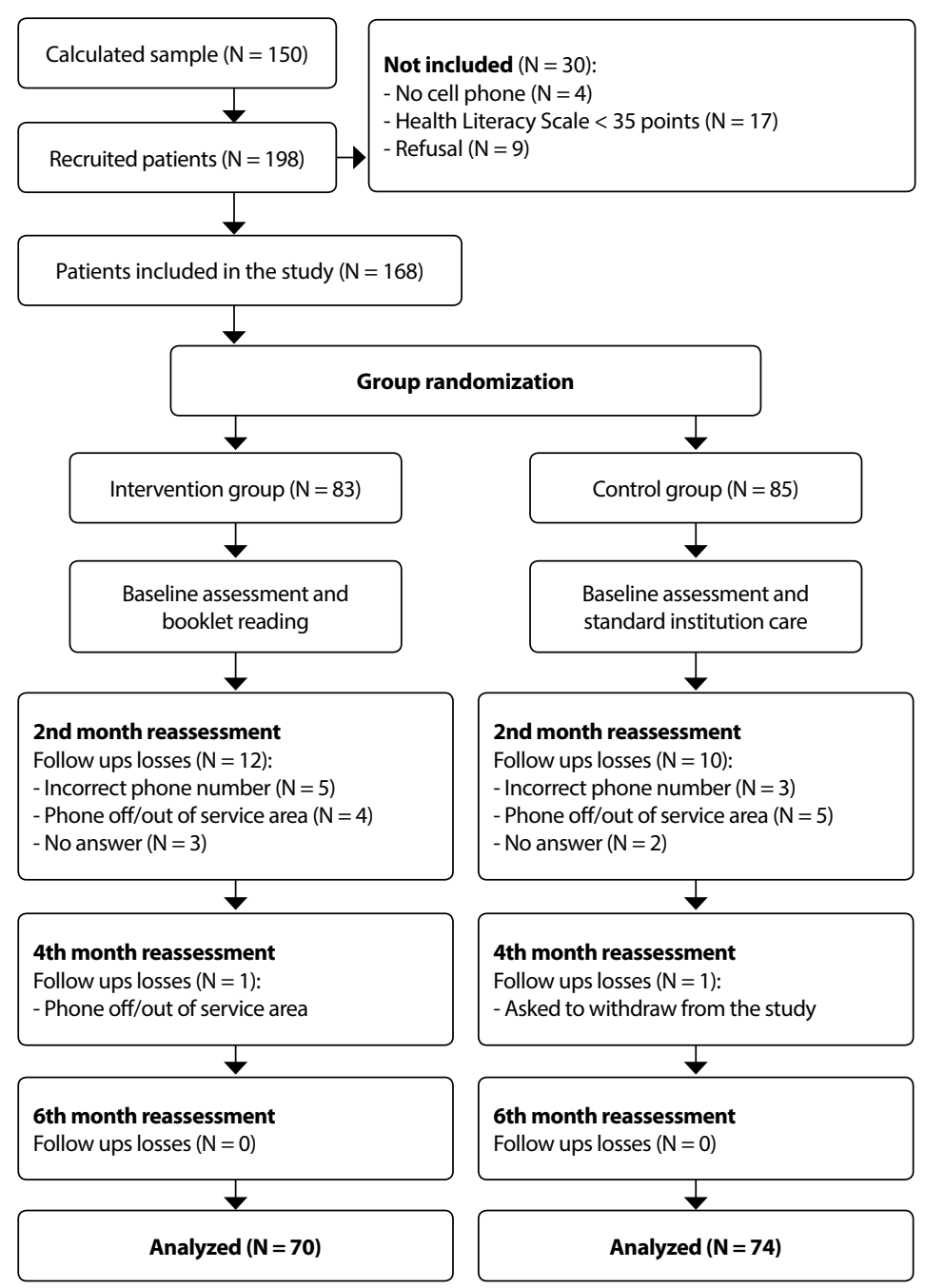

Figure 1 - Clinical trial flowchart, Fortaleza, Ceará, Brazil, 2020

Of the 144 PLHIV, most were male, brown, single, catholic, employed, from the sexual exposure category, heterosexual, and with a serodiscordant partner (Table 1).

The most used antiretroviral drug was lamivudine $(93.6 \% ; p=$ $0.344)$. Mean values and standard deviations for the intervention and control groups were, respectively: age $(44.2 \pm 12.4 ; 40.6 \pm$ $11.5 ; p=0.074)$, years of study $(10.8 \pm 3.5 ; 11.0 \pm 3.8 ; p=0.979)$, family income (in reais) $(2,239.0 \pm 1,400.0 ; 2,738.2 \pm 2,142.6 ; p$ $=0.310$ ), time since diagnosis (in years) $(8.6 \pm 5.7 ; 8.6 \pm 5.3 ; \mathrm{p}=$ 0.849 ), time on ART (in months) $(95.9 \pm 59.5 ; 101.1 \pm 65.7 ; p=$ $0.661), \mathrm{CD} 4+\mathrm{T}$ lymphocytes count (cells $\left./ \mathrm{mm}^{3}\right)(615.3 \pm 237.6$; $703.0 \pm 349.1 ; p=0.141)$ and viral load (copies $/ \mathrm{ml})(395.6 \pm$ 2,650.0; $56.0 \pm 316.9 ; p=0.662$ ).

The majority reported irregular physical exercise $(53.5 \% ; p=$ $0.390)$, moderate salt consumption $(52.8 \% ; p=0.392)$, denied the use of alcoholic beverages $(60.4 \% ; p=0.921)$, smoking $(61.8 \%$, $p=0.708)$, and illegal drugs (95.1\%; $p=0.755)$. There were hypertensive $(22.9 \% ; p=0.414)$ and diabetics $(13.9 \% ; p=0.414)$; and family history of hypertension (76.4\%; $p=0.332)$, diabetes $(49.3 \% ; p=0.407)$, and cancer $(49.3 \% ; p=0.620)$. Mean values and standard deviations for the intervention and control groups, respectively: systolic $\mathrm{BP}(\mathrm{mmHg})(118.7 \pm 11.9 ; 117.2 \pm 12.8 ; \mathrm{p}=$
0.434), diastolic BP (mmHg) $(750.9 \pm 11.9 ; 75.9 \pm 13.3$; $\mathrm{p}=0.738$ ), waist circumference (in centimeters) ( $88.8 \pm$ $10.5 ; 89.3 \pm 11.3 ; p=0.683$ ), weight (in kilograms) $(70.8$ $\pm 13.4 ; 71.5 \pm 11.8 ; p=0.649$ ), height (in centimeters) $(1.64 \pm 0.0 ; 1.64 \pm 0.0 ; p=0.979)$ and BMI (kilogram/ meter $\left.^{2}\right)(26.1 \pm 4.5 ; 26.1 \pm 3.4 ; p=0.832)$.

Thus, at baseline, the intervention and control groups were comparable in terms of variables. In the KAP Survey analysis, in terms of knowledge, the score was adequate within the intervention (94.3\%) and control (97.3\%) groups, with the respective means and standard deviations: $91.0 \pm 15.7 ; 90.9 \pm 9.5 ; p=0.196$. Attitude had adequate scores in the intervention (91.4\%) and control (91.9\%) groups, with the respective means and standard deviations: $90.2 \pm 12.4 ; 89.3 \pm 13.0 ; p=0.592$. In practice, half of the PLHIV in the intervention group had an adequate score (50.0\%); and within the control group, $55.4 \%$ had an inadequate score (55.4\%), with the respective means and standard deviations (67.2 \pm $19.9 ; 67.0 \pm 19.7 ; p=0.987)$. For the reassessments, the assumption of alignment analysis of the transformed ranks showed that the set of $F$ statistics for the Knowledge, Attitude and Practice variables was close to 0 , with high $p$ values. Rank alignment assumption was acceptable for repeated measures analysis.

Table 2 shows the confidence intervals for estimated marginal means of the Knowledge variable for each group and assessment time, as well as the contrast assessment.

According to Table 2, in knowledge, the differences in scores had the following variations: differences between the intervention and control groups $(p<$ $0.037)$ and intra-moment variations $(p<0.001)$. The intervention with the booklet generated statistical differences due to the isolated influence of the Time factor and the isolated influence of the Group factor, but not due to the interaction of both factors. Contrast analysis showed statistical differences when comparing the measurements from the sixth month with those from earlier periods $(p<0.001$; $p<0.001 ; p=0.023$ ). Thus, as for the isolated effect of the Time factor, the impact on knowledge occurred late, but with a gradual increase at each assessment. Although the confidence intervals for estimated marginal means of knowledge for the intervention and control groups overlap, demonstrating that the two groups appear to have similar knowledge, the contrast assessment showed that the intervention implied a higher knowledge score in the intervention group when compared to control (307 versus 270; $p=0.037$ ), in relation to the isolated effect of the Group factor. In post-hoc comparisons between the intervention and control groups, there was no difference in the interaction between Time and Group factors. This probably highlights the absence of a significant effect per group, when considering the different moments of assessment for the Knowledge variable, corroborating the initial idea that the intervention effect only occurs later with better performance in the intervention group.

Table 3 shows the confidence intervals for estimated marginal means of the Attitude variable for each group and assessment moment, and assessment by contrasts. 
Table 1 - Sociodemographic, epidemiological, and baseline clinical characterization of people living with HIV in the intervention $(\mathrm{N}=70)$ and control $(\mathrm{N}=74)$ groups, Fortaleza, Ceará, Brazil, 2020

\begin{tabular}{|c|c|c|c|c|c|c|c|}
\hline \multirow{2}{*}{$\begin{array}{l}\text { Sociodemographic, } \\
\text { epidemiological and clinical } \\
\text { variables }\end{array}$} & \multicolumn{2}{|c|}{$\begin{array}{l}\text { Intervention } \\
\text { group }\end{array}$} & \multicolumn{2}{|c|}{$\begin{array}{l}\text { Control } \\
\text { group }\end{array}$} & \multicolumn{2}{|c|}{ Total } & \multirow[t]{2}{*}{$\begin{array}{c}p \\
\text { value }\end{array}$} \\
\hline & n & $\%$ & n & $\%$ & $\mathbf{n}$ & $\%$ & \\
\hline Sex & & & & & & & 0.551 \\
\hline Male & 45 & 64.2 & 44 & 59.4 & 89 & 61.8 & \\
\hline Female & 25 & 35.8 & 30 & 40.6 & 55 & 38.2 & \\
\hline Skin color & & & & & & & 0.464 \\
\hline White & 17 & 24.3 & 13 & 17.5 & 30 & 20.8 & \\
\hline Black & 11 & 15.7 & 11 & 14.9 & 22 & 15.3 & \\
\hline Brown & 39 & 55.7 & 49 & 66.2 & 88 & 61.1 & \\
\hline Yellow & 3 & 4.3 & 1 & 1.4 & 4 & 2.8 & \\
\hline Marital status & & & & & & & 0.333 \\
\hline Sinqle & 39 & 55.8 & 34 & 45.9 & 73 & 50.8 & \\
\hline Married/living together & 18 & 25.7 & 28 & 37.9 & 46 & 31.9 & \\
\hline Divorced/separated & 9 & 12.7 & 6 & 8.1 & 15 & 10.4 & \\
\hline Widowed & 4 & 5.8 & 6 & 8.1 & 10 & 6.9 & \\
\hline Religion & & & & & & & 0.337 \\
\hline Catholic & 41 & 58.5 & 43 & 58.1 & 84 & 58.3 & \\
\hline Evangelical & 13 & 18.4 & 18 & 24.3 & 31 & 21.5 & \\
\hline No religion & 12 & 17.0 & 6 & 8.1 & 18 & 12.5 & \\
\hline Other & 1 & 1.3 & 4 & 5.4 & 5 & 3.5 & \\
\hline Spiritist & 3 & 4.8 & 3 & 4.1 & 6 & 4.2 & \\
\hline Occupational situation & & & & & & & 0.627 \\
\hline Employed & 44 & 62.7 & 41 & 55.4 & 85 & 59.1 & \\
\hline Unemployed & 14 & 20.0 & 21 & 28.4 & 35 & 24.2 & \\
\hline Retired & 9 & 12.7 & 9 & 12.2 & 18 & 12.5 & \\
\hline On leave & 3 & 4.6 & 3 & 4.0 & 6 & 4.2 & \\
\hline Exposure category & & & & & & & 0.657 \\
\hline Sexual & 65 & 92.7 & 70 & 94.6 & 135 & 93.8 & \\
\hline Blood transfusion & 3 & 4.4 & 2 & 2.6 & 5 & 3.4 & \\
\hline Injecting drug user & 2 & 2.9 & 1 & 1.4 & 3 & 2.1 & \\
\hline Vertical transmission & 0 & 0.0 & 1 & 1.4 & 1 & 0.7 & \\
\hline Sexual orientation & & & & & & & 0.208 \\
\hline Heterosexual & 40 & 57.2 & 44 & 59.5 & 84 & 58.4 & \\
\hline Homosexual & 22 & 31.4 & 25 & 33.8 & 47 & 32.6 & \\
\hline Bisexual & 8 & 11.4 & 3 & 4.0 & 11 & 7.6 & \\
\hline Transgender & 0 & 0.0 & 2 & 2.7 & 2 & 1.4 & \\
\hline Partner's anti-HIV serology & & & & & & & 0.372 \\
\hline Positive & 14 & 20.0 & 16 & 21.6 & 30 & 20.8 & \\
\hline Negative & 15 & 21.4 & 24 & 32.4 & 39 & 27.1 & \\
\hline Without partner & 37 & 52.9 & 32 & 43.3 & 69 & 47.9 & \\
\hline Doesn't know/didn't undergo & 4 & 5.7 & 2 & 2.7 & 6 & 4.2 & \\
\hline
\end{tabular}

Table 2 - Post-hoc comparisons of estimated marginal means of the ranks in the Knowledge item for time (four evaluation moments) and group (intervention and control), Fortaleza, Ceará, Brazil, 2020

\begin{tabular}{lccccc}
\hline 1. Time & EMM & SE & df & \multicolumn{2}{c}{ C195\% } \\
Baseline & 255 & 13.3 & 460 & 229 & 281 \\
2 months & 266 & 13.3 & 460 & 240 & 292 \\
4 months & 294 & 13.3 & 460 & 267 & 320 \\
6 months & 339 & 13.3 & 460 & 313 & 366 \\
1.1. Contrasts & Estimate & SE & df & $\mathbf{t}$ & $\boldsymbol{p}$ value \\
Baseline - 2 months & -11.2 & 16 & 426 & -0.70 & 0.897 \\
Baseline - 4 months & -38.6 & 16 & 426 & -2.41 & 0.077 \\
Baseline - 6 months & -84.4 & 16 & 426 & -5.27 & $<\mathbf{0 . 0 0 1}$ \\
2 months - 4 months & -27.4 & 16 & 426 & -1.71 & 0.321 \\
2 months - 6 months & -73.1 & 16 & 426 & -4.57 & $<\mathbf{0 . 0 0 1}$ \\
4 months - 6 months & -45.8 & 16 & 426 & -2.86 & 0.023 \\
2. Group & EMM & SE & df & \multicolumn{2}{c}{ Cl95\% } \\
Control & 270 & 12.5 & 142 & 245 & 295 \\
Intervention & 307 & 12.5 & 142 & 282 & 332 \\
2.1. Contrasts & Estimate & SE & df & $\mathbf{t}$ & $\boldsymbol{p}$ value \\
Control - Intervention & -37 & 17.6 & 142 & -2.10 & 0.037
\end{tabular}

$\overline{\text { EMM-Estimated Marginal Means; SE-Standard Error; } d f \text {-Degrees of freedom;IC95\%-Confidence }}$ interval of $95 \%$; $t$ - T-tests.
Table 3 - Attitude post-hoc comparisons of estimated marginal means for time (four assessment moments) and group (intervention and control), Fortaleza, Ceará, Brazil, 2020

\begin{tabular}{lccccc}
\hline 1. Time & EMM & SE & df & \multicolumn{2}{c}{ Cl95\% } \\
Baseline & 239 & 12.8 & 424 & 214 & 264 \\
2 months & 304 & 12.8 & 424 & 279 & 330 \\
4 months & 318 & 12.8 & 424 & 293 & 343 \\
6 months & 292 & 12.8 & 424 & 267 & 318 \\
1.1. Contrasts & Estimate & SE & df & t & p value \\
Baseline - 2 months & -65.7 & 14.7 & 426 & -4.47 & $<\mathbf{0 . 0 0 1}$ \\
Baseline - 4 months & -79.6 & 14.7 & 426 & -5.41 & $<\mathbf{0 . 0 0 1}$ \\
Baseline - 6 months & -53.8 & 14.7 & 426 & -3.65 & 0.002 \\
2 months - 4 months & -13.9 & 14.7 & 426 & -0.94 & 0.782 \\
2 months - 6 months & 12.0 & 14.7 & 426 & 0.81 & 0.848 \\
4 months - 6 months & 25.9 & 14.7 & 426 & 1.76 & 0.296 \\
2. Group & EMM & SE & df & \multicolumn{2}{c}{ Cl95\% } \\
Control & 286 & 12.8 & 142 & 261 & 311 \\
Intervention & 291 & 12.8 & 142 & 266 & 316 \\
2.1. Contrasts & Estimate & SE & df & t & p value \\
Control - Intervention & -4.85 & 18.1 & 142 & -0.27 & 0.789 \\
\hline
\end{tabular}

EMM-Estimated Marginal Means; SE-Standard Error; df-Degrees of freedom;/C95\%-Confidence interval of $95 \% ; t$ - $T$-tests.

According to Table 3, regarding attitudes, the differences in measurement values are explained by the variations: intra-moment assessment differences $(p<0.001)$ and differences produced by the interaction between groups in the intra-moment assessment comparison $(p=0.026)$. Booklet intervention generated significant changes that seem to be determined by the Time factor, with some contribution from the interaction between Time and Group. The analyses showed statistically significant differences when comparing baseline measurements, regardless of group, with measurements at the three subsequent time points $(p<0.001 ; p<0.001 ; p=0.002)$. As for the isolated effect of the Time factor, the intervention implied an increase in the score in the Attitude item in the second, fourth, and sixth month reassessments when compared to baseline. The analyses did not show statistically significant differences when comparing the measurements obtained in the intervention and control groups, regardless of the time of measurement. That is, regarding the isolated effect of the Group factor, the intervention and control groups had similar scores after the intervention (291 versus $286 ; p=0.789$ ). Furthermore, the scores of the attitude item between the intervention and control groups were statistically different when comparing the baseline with the measures of the second ( $p=0.003)$ and fourth months $(p=0.040)$. Thus, regarding the effect of the interaction between Time and Group, the booklet intervention implied significant differences between the intervention and control groups in the two- and four-month reassessments when compared to the baseline (Table 3).

Table 4 shows the confidence intervals for estimated means of the Practice variable for each group and assessment moment; and assessment by contrasts.

According to Table 4, regarding the Practice item, the differences in scores are explained by the variations: differences between the intervention and control groups $(p<0.001)$, intramoment assessment differences $(p<0.001)$ and differences in the interaction between groups in the intra-moment assessment comparison $(p<0.001)$. The booklet caused a significant change between groups and assessment moments. Analyses showed statistically significant differences when comparing baseline 
measurements, regardless of group, with measurements at the three subsequent time points $(p=0.003 ; p<0.001 ; p<0.001)$. This fact is repeated when comparing the measurement of the second with the sixth month $(p=0.008)$. As for the isolated effect of the Time factor, the booklet increased the score in the practice item in both groups, in the second, fourth, and sixth month reassessments compared to baseline, and increased the score in the sixth month reassessment, when compared to the second month. As for the isolated effect of the Group factor, the intervention generated higher scores in the Practice category in the intervention group compared to control (338 versus 239; $p<0.001)$, regardless of the time of measurement. The Practice variable scores between intervention and control groups were statistically different when comparing baseline with subsequent moments $(p<0.001 ; p<0.001 ; p<0.001)$. As the method of comparison is based on difference of differences, it was concluded that the positive value of the estimate refers to the highest values obtained in the intervention group (estimate of baseline values with subsequent moments, respectively: 108.07; 109.22; 138.24). As for the effect of the interaction between time and group, the booklet led to a significantly greater change in the intervention group compared to the control group in the second, fourth, and sixth month reassessments compared to baseline.

Table 4 - Practice post-hoc comparisons of estimated marginal means of ranks for time (four assessment moments) and group (intervention and control), Fortaleza, Ceará, 2020

\begin{tabular}{lccccc}
\hline 1. Time & EMM & SE & df & \multicolumn{2}{c}{ Cl95\% } \\
Baseline & 232 & 13.6 & 341 & 206 & 259 \\
2 months & 281 & 13.6 & 341 & 254 & 308 \\
4 months & 315 & 13.6 & 341 & 288 & 342 \\
6 months & 326 & 13.6 & 341 & 299 & 352 \\
1.1. Contrasts & Estimate & SE & df & $\mathbf{t}$ & $\boldsymbol{p}$ value \\
Baseline - 2 months & -48.5 & 14 & 426 & -3.46 & 0.003 \\
Baseline - 4 months & -83.0 & 14 & 426 & -5.92 & $<\mathbf{0 . 0 0 1}$ \\
Baseline - 6 months & -93.4 & 14 & 426 & -6.67 & $<\mathbf{0 . 0 0 1}$ \\
2 months - 4 months & -34.5 & 14 & 426 & -2.46 & 0.068 \\
2 months - 6 months & -44.9 & 14 & 426 & -3.20 & 0.008 \\
4 months - 6 months & -10.4 & 14 & 426 & -0.74 & 0.880 \\
2. Group & EMM & SE & df & \multicolumn{2}{c}{ Cl95\% } \\
Control & 239 & 14.6 & 142 & 211 & 268 \\
Intervention & 338 & 14.6 & 142 & 309 & 366 \\
2.1. Contrasts & Estimate & SE & df & $\mathbf{t}$ & $\boldsymbol{p}$ value \\
Control - Intervention & -98 & 20.7 & 142 & -4.74 & $<\mathbf{0 . 0 0 1}$
\end{tabular}

EMM-Estimated Marginal Means; SE-Standard Error; df-Degrees of freedom;IC95\%-Confidence interval of $95 \%$; $t$ - T-tests.

\section{DISCUSSION}

This clinical trial showed that the intervention with the educational booklet improved Knowledge, Attitudes, and Practices about healthy lifestyle in PLHIV. The booklet is a printed material with the purpose of conveying information that helps patients, family members, caregivers, and the community to make more assertive decisions about health. This technology can change daily habits by providing clear guidelines and highlighting the benefits of the proposed care ${ }^{(29)}$. This study corroborates other studies, in which the evaluated booklets were effective in improving adherence to $\mathrm{ART}^{(29-31)}$ and reducing the use of illicit drugs ${ }^{(29)}$ in PLHIV.

In the baseline assessment of the KAP Survey, PLHIV had adequate scores in the Knowledge and Attitude items, but inadequate in Practice, confirming other research involving people with chronic diseases ${ }^{(13,32)}$. Knowledge is understood as the ability to remember or understand aspects of the learning process, as well as understand its applicability in problem solving. Attitude consists of having opinions, beliefs, and feelings linked to achieving goals or situations, while practice is the act of implementing the action ${ }^{(11)}$. Thus, the lack of knowledge and awareness can be a barrier that prevents the individual from achieving a healthier lifestyle, presuming that increasing knowledge intensifies preventive behavior ${ }^{(13)}$.

However, knowledge alone may not promote a direct impact on lifestyle, placing motivation as a necessary condition to improve habits. Furthermore, other factors can also interfere in the process, such as the consumption of legal and illegal drugs, level of complexity of the therapeutic regimen, education, unemployment, and ingestion of processed foods. According to a study with hypertensive patients, knowledge and attitude are not enough to change health practices, as most patients only feel the need to change their lifestyle when diseases become symptomatic or when they present complications, which requires strategies to increase Knowledge, Attitude and Practice about healthy lifestyle $\mathrm{e}^{(33)}$.

After booklet intervention, regarding Knowledge, there was no statistical difference between the intervention and control group pertaining Time and Group factor, but the analysis by contrasts showed that the impact of the booklet came later, although it had a gradual increase in each assessment. In agreement with these findings, studies have shown that the use of the educational booklet has already been effective in increasing knowledge about HIV in patients ${ }^{(30,34)}$. Thus, interventions using booklets, in general, are effective to improve knowledge over time, but a commitment to constant and attentive reading of the material is necessary. Furthermore, increasing the desired knowledge is not always a guarantee of a more responsible behavior, and it is necessary to plan activities for greater adherence to their guidelines, since the change in attitude occurs after the introjection of the awakened and adopted sense of responsibility by the individual, and not by imposition or obligation ${ }^{(35)}$.

Regarding the Attitude item, the use of the booklet generated significant differences between the intervention and control groups in the two- and four-month reassessments when compared to the baseline, but the Group factor, in isolation, did not demonstrate the superiority of the intervention group over the control group. In this regard, a study showed that a booklet associated with educational counseling resulted in an increase in attitudes towards self-care for a healthy lifestyle in hospitalized patients ${ }^{(36)}$. Another study, carried out in Iran, showed that the booklet combined with counseling and other educational strategies was effective for the attitude of reducing self-medication in diabetics ${ }^{(37)}$.

Health professionals need new skills to care for PLHIV, as the infection has become a chronic condition, and comprehensive care is essential, as well as practices that increase empowerment, autonomy, and responsibility for the treatment. Thus, health education can be effective in improving the lifestyle of this population. Educational materials represent an emancipatory technology, as they enable HIV patients to change attitudes, incorporate healthy habits, enhance their self-care, favoring the 
process of communication and guidance between the health team, patients, and families ${ }^{(29)}$.

In terms of Practice, the booklet intervention implied a significant change in the intervention group compared to the control group in the reassessments of two, four, and six months compared to baseline. This confirms studies that reported the effectiveness of educational booklets in improving the lifestyle of middle-aged women ${ }^{(38-39)}$. The effectiveness of printed materials was also evaluated in a systematic review, which found its positive impact on the population, but emphasized that, in order to obtain better results, they should be used alongside professional guidance ${ }^{(40)}$ as, professional guidance by itself, does not promote the same results as when additional printed materials are used, which seek to elucidate the intended information being conveyed ${ }^{(41)}$.Thus, printed educational materials are useful for building knowledge and disseminating clinical information, being a low-cost means of dissemination to improve the provision of health care $^{(42)}$, in addition to being important when made available for use in the home environment ${ }^{(43)}$.

\section{Study limitations}

One limitation was the fact that the booklet was only evaluated with PLHIV at an outpatient level, as in contexts of hospitalization and deprivation of liberty, many activities suggested could not be performed. The COVID-19 pandemic interfered in the last reassessment of the patients, which would be in person, but it was done by telephone. Patients return to the clinic every six months, but due to COVID-19, the flow of care was changed.
Furthermore, despite the benefits of the booklet, social isolation may have interfered with some guidelines, such as those on the practice of physical exercise.

\section{Contributions to the field of Nursing, Health and Public Policy}

Based on this clinical trial, we highlight the importance of educational booklets and printed materials that patients take home, as an out-of-office extension of care provided by professionals, as the intervention was effective in improving Knowledge, Attitudes, and Practices of a healthy lifestyle in PLHIV. The study contributed to the spread of health promotion practices to the target audience, allowing the reduction of long-term financial costs, especially due to the consequences of an unhealthy lifestyle. Randomized clinical trial-type research is suggested to assess other strategies focusing on the quality of life of people with HIV, because, due to ART, the infection has become a chronic condition, and these patients need health guidance that go beyond treating opportunistic infections. New studies could also use the booklet associated with other interventions and health care contexts.

\section{CONCLUSION}

The study found that most of the assessed PLHIV had adequate knowledge and attitude and inadequate practice about healthy lifestyles prior to the intervention; and that the educational booklet was effective in improving Knowledge, Attitude and Practice about healthy lifestyle, items analyzed through the KAP Survey.

\section{REFERENCES}

1. Umar DM, Naidoo P. Prevalence and predictors of diabetes mellitus among persons living with HIV: a retrospective cohort study conducted in 4 public healthcare facilities in KwaZulu-Natal. BMC Public Health. 2021;21(1):288. https://doi.org/10.1186/s12889-021-10318-6

2. Hatleberg $\mathrm{Cl}$, Ryom L, Monforte AA, Fontas E, Reiss P, Kirk O, et al. Association between exposure to antiretroviral drugs and the incidence of hypertension in HIV-positive persons: the data collection on adverse events of anti-HIV drugs (D:A:D) study. HIV Med. 2018;19(9):605-18. https://doi.org/10.1111/hiv.12639

3. Sewale $Y$, Afenigus AD, Haile D, Shiferaw WS. Magnitude of hypertension and associated factors among human immunodeficiency virus positive adults receiving anti-retroviral therapy at Debre Markos Referral Hospital, Northwest, Ethiopia. HIV AIDS (Auckl). 2020;12:629-37. https://doi.org/10.2147/HIV.S280630

4. Noubissi EC, Katte J-C, Sobngwi E. Diabetes and HIV. Curr Diab Rep. 2018;18(11):125. https://doi.org/10.1007/s11892-018-1076-3

5. Roozen GVT, Meel R, Peper J, Venter WVF, Barth RE, Grobbee DE, et al. Electrocardiographic and echocardiographic abnormalities in urban African people living with HIV in South Africa. PLoS One. 2021;16(2):e0244742. https://doi.org/10.1371/journal.pone.0244742

6. De Francesco D, Underwood J, Bagkeris E, Boffito M, Post FA, Mallon PWG, et al. Depression, lifestyle factors and cognitive function in people living with HIV and comparable HIV-negative controls. 2019;20(4):274-85. https://doi.org/10.1111/hiv.12714

7. Cooper V, Clatworthy J, Harding R, Whetham J; Emerge Consortium. Measuring quality of life among people living with HIV: a systematic review of reviews. Health Qual Life Outcomes. 2017;15(1):220. https://doi.org/10.1186/s12955-017-0778-6

8. World Health Organization (WHO). Envelhecimento ativo: uma política de saúde [Internet]. Brasília, DF: Organização Pan-Americana da Saúde; 2005[cited 2019 Dec 20]. Available from: https://bvsms.saude.gov.br/bvs/publicacoes/envelhecimento_ativo.pdf

9. Nahas MV, Barros MVG, Francalacci VL. O pentáculo do bem-estar: base conceitual para avaliação do estilo de vida de indivíduos e grupos. Rev Bras Ativ Fis Saude. 2000;5(2):48-59. https://doi.org/10.12820/rbafs.v.5n2p48-59

10. Farhodimoghadam $M$, Heydarpour S, Salari N, Jaberghaderi N. The effect of cognitive-behavioral counseling on lifestyle in pregnant women: a randomized controlled clinical trial. J Med Life. 2020;13(2):187-94. https://doi.org/10.25122/jml-2019-0163

11. Ferreira DS, Bernardo FMS, Costa EC, Maciel NS, Costa RL, Carvalho CML. Knowledge, attitude and practice of nurses in the detection of breast câncer. Esc Anna Nery. 2020;24(2):e20190054. https://doi.org/10.1590/2177-9465-ean-2019-0054 
12. Mekonnen $\mathrm{Y}$, Hussien N. Self-care related knowledge, attitude, and practice and associated factors among patients with type 2 diabetes in JMC, Ethiopia. Diabetes Metab Syndr Obes. 2021;14:535-46. https://doi.org/10.2147/DMSO.S296112

13. Bogale S, Mishore KM, Tola A, Mekuria AN, Ayele Y. Knowledge, attitude and practice of lifestyle modification recommended for hypertension management and the associated factors among adult hypertensive patients in Harar, Eastern Ethiopia. SAGE Open Med. 2020;8:2050312120953291. https://doi.org/10.1177/2050312120953291

14. Liu C, Song X, Hao H. Educational video followed by retelling bowel preparation process to improve colonoscopy bowel preparation quality: a prospective nursing intervention study. Med Sci Monit. 2018;24:6029-37. https://doi.org/10.12659/MSM.909572

15. Jesus GJ, Caliari JS, Oliveira LB, Queiroz AAFLN, Figueiredo RM, Reis RK. Construction and validation of educational material for the health promotion of individuals with HIV. Rev Latino-Am Enfermagem. 2020;28:e3322. https://doi.org/10.1590/1518-8345.3748.3322

16. Simula AS, Jenkins $H J$, Holopainen $R$, Oura $P$, Korniloff $K$, Häkkinen $A$, et al. Transcultural adaption and preliminary evaluation of "understanding low back pain" patient education booklet. BMC Health Serv Res. 2019;19(1):1010. https://doi.org/10.1186/ s12913-019-4854-y

17. Carvalho KM, Figueiredo MLF, Galindo Neto NM, Sá GGM. Construction and validation of a sleep hygiene booklet for the elderly. Rev Bras Enferm. 2019;72(suppl 2):214-20. https://doi.org/10.1590/0034-7167-2018-0603

18. Ministério da Saúde (BR). Resolução $n^{\circ} 466 / 2012$, de 12 de dezembro de 2012. Aprova as diretrizes e normas regulamentadoras de pesquisa envolvendo seres humanos [Internet]. Brasília, DF: MS; 2012 [cited 2018 Dec 13]. Available from: https://bvsms.saude.gov.br/bvs/saudelegis/ cns/2013/res0466_12_12_2012.html

19. Schulz KF, Altman DG, Moher D; Consort Group. CONSORT 2010 statement: updated guidelines for reporting parallel group randomised trials. BMJ. 2010;340:c332. https://doi.org/10.1136/bmj.c332

20. Batista MJ, Marques ACP, Silva Jr MF, Alencar GP, Sousa MLR. Translation, cross-cultural adaptation and psychometric evaluation of Brazilian Portuguese version of the 14-item health literacy scale. Cienc Saude Coletiva. 2020;25(7):2847-57. https://doi. org/10.1590/1413-81232020257.22282018

21. Fontenele MSM, Cunha GH, Lopes MVO, Siqueira LR, Lima MAC, Moreira LA. Development and evaluation of a booklet to promote ealthy lifestyle in people with HIV. Rev Bras Enferm. 2021;74(5):e20200113. https://doi.org/10.1590/0034-7167-2020-0113

22. Prochaska JO, Norcross JC, Diclemente CC. Applying the stages of change. Psychother Australia [Internet]. 2013[cited 2021 Jan 20];19(2):1015. Available from: https://search.informit.org/doi/pdf/10.3316/informit.254435778545597?download=true

23. Suka $M$, Odajima T, Kasai $M$, Igarashi $A$, Ishikawa $H$, Kusama $M$, et al. The 14-item health literacy scale for Japanese adults (HLS-14). Environ Health Prev Med. 2013;18(5):407-15. https://doi.org/10.1007/s12199-013-0340-z

24. Reis FB, Lopes AD, Faloppa F, Ciconelli RM. A importância da qualidade dos estudos para a busca da melhor evidência. Rev Bras Ortop. 2008;43(6):209-16. https://doi.org/10.1590/S0102-36162008000600001

25. Cunha GH, Galvão MTG. Nursing diagnoses in patients with human immunodeficiency virus/acquired immunodeficiency syndrome in outpatient care. Acta Paul Enferm. 2010;23(4):526-32. https://doi.org/10.1590/\$0103-21002010000400013

26. Cunha GH, Galvão MTG. Sociodemographic context of patients with HIV/aids attended in nursing consultation. J Nurs UFPE. 2011;5(3):71321. https://doi.org/10.5205/reuol.1262-12560-1-LE.0503201120. Portuguese.

27. Fontenele MSM. Desenvolvimento e avaliação de uma cartilha educativa para promoção do estilo de vida saudável em pessoas com HIV [dissertation on Internet]. Fortaleza: Universidade Federal do Ceará; 2019[cited 2021 Aug 16]. Available from: http://www.repositorio.ufc.br/ handle/riufc/49625

28. Wobbrock JO, Findlater L, Gergle D, Higgins JJ. The aligned rank transform for nonparametric factorial analyses using only anova procedures. In: Proceedings of the SIGCHI Conference on Human Factors in Computing Systems. Vancouver: ACM Press; 2011. p. 143-6. https://doi.org/10.1145/1978942.1978963

29. Parsons JT, John SA, Millar BM, Starks TJ. Testing the efficacy of combined motivational interviewing and cognitive behavioral skills training to reduce methamphetamine use and improve HIV medication adherence among HIV-positive gay and bisexual men. AIDS Behav. 2018;22(8):2674-86. https://doi.org/10.1007/s10461-018-2086-5

30. Rajesh R, Vidyasagar S, Varma DM, Guddattu V, Hammed A. Evaluating the impact of educational interventions on use of highly active antiretroviral therapy and adherence behavior in indian human immunodeficiency virus positive patients: prospective randomized controlled study. J AIDS Clin Res. 2013;4:8. https://doi.org/10.4172/2155-6113.1000231

31. Holstad MM, Dilorio C, Kelley ME, Resnicow K, Sharma S. Group motivational interviewing to promote adherence to antiretroviral medications and risk reduction behaviors in HIV infected women. AIDS Behav. 2011;15(5):885-96. https://doi.org/10.1007/s10461-010-9865-y

32. Buda ES, Hanfore LK, Fite RO, Buda AS. Lifestyle modification practice and associated factors among diagnosed hypertensive patients in selected hospitals, South Ethiopia. Clin Hypertens. 2017;23:26. https://doi.org/10.1186/s40885-017-0081-1

33. Jafari F, Shahriari M, Sabouhi F, Farsani AK, Babadi ME. Effects of a lifestyle modification program on knowledge, attitude and practice of hypertensive patients with angioplasty: a randomized controlled clinical trial. Int J Community Based Nurs Midwifery [Internet]. 2016[cited 2020 Oct 23];4(4):286-96. Available from: https://www.ncbi.nlm.nih.gov/pmc/articles/PMC5045973/

34. Schafer JJ, Naples JG, Pizzi LT, DeSimone JA Jr. The effects of a pharmacist-delivered patient education programme on retention in human immunodeficiency virus care: a pilot study. J Pharm Health Serv Res. 2015;6(2):83-9. https://doi.org/10.1111/jphs.12092 
35. Rufino EC, Andrade SSC, Leadebal ODCP, Brito KKG, Silva FMC, Santos SH. Women's knowledge about sti/aids: working with health education. Cienc Cuid Saude. 2016;15(2):304-12. https://doi.org/10.4025/cienccuidsaude.v15i2.26287

36. Navidian A, Yaghoubinia F, Ganjali A, Khoshsimaee S. The effect of self-care education on the awareness, attitude, and adherence to self-care behaviors in hospitalized patients due to heart failure with and without depression. PLoS One. 2015;10(6):e0130973. https://doi. org/10.1371/journal.pone.0130973

37. Jeihooni AK, Barati M, Kouhpayeh A, Kashfi SM, Harsini PA, Rahbar M. The effect of educational intervention based on BASNEF model on self-medication behavior of type 2 diabetic patients. Indian J Endocrinol Metab. 2019;23(6):616-22. https://doi.org/10.4103/ijem. IJEM_436_19

38. Karimlou V, Charandabi SM-A, Malakouti J, Mirghafourvand M. Effect of counselling on health-promoting lifestyle and the quality of life in Iranian middle-aged women: a randomised controlled clinical trial. BMC Health Serv Res. 2019;19(1):350. https://doi.org/10.1186/ s12913-019-4176-0

39. Mahdipour N, Shahnazi H, Hassanzadeh A, Sharifirad G. The effect of educational intervention on health promoting lifestyle: focusing on middle-aged women. J Educ Health Promot. 2015;4:51. https://doi.org/10.4103/2277-9531.162334

40. Livingstone-Banks J, Ordóñez-Mena JM, Hartmann-Boyce J. Print-based self-help interventions for smoking cessation. Cochrane Database Syst Rev. 2019;1(1):CD001118. https://doi.org/10.1002/14651858.CD001118.pub4

41. Pimmer C, Mateescu M, Zahn C, Genewein U. Smartphones as multimodal communication devices to facilitate clinical knowledge processes: randomized controlled trial. J Med Internet Res. 2013;15(11):e263. https://doi.org/10.2196/jmir.2758

42. Grudniewicz A, Kealy R, Rodseth RN, Hamid J, Rudoler D, Straus SE. What is the effectiveness of printed educational materials on primary care physician knowledge, behaviour, and patient outcomes: a systematic review and metaanalyses. Implement Sci. 2015;10:164. https:// doi.org/10.1186/s13012-015-0347-5

43. Ertel AE, Kaiser TE, Abbott DE, Shah SU. Use of video-based education and tele-health home monitoring after liver transplantation: results of a novel pilot study. Surgery. 2016;160(4):869-76. https://doi.org/10.1016/j.surg.2016.06.016 